Primljen / Received: 22.8.2012.

Ispravljen / Corrected: 24.11.2012.

Prihvaćen / Accepted: 29.11.2012.

Dostupno online / Available online: 15.12.2012.

\section{Influence of contact stresses on bearing capacity of traditional stone columns}

Authors:

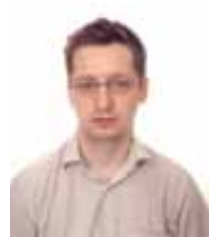

Josip Atalić, PhD. CE

University of Zagreb

Faculty of Civil Engineering

atalic@grad.hr

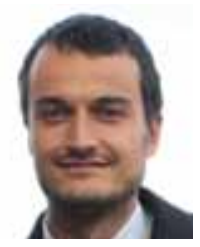

Mario Uroš, MCE

University of Zagreb

Faculty of Civil Engineering

uros@igrad.hr

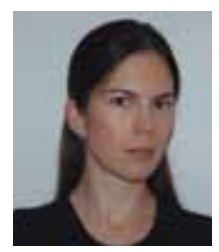

Marta Šavor, MCE

University of Zagreb

Faculty of Civil Engineering

msavor@grad.hr

\section{Josip Atalić, Mario Uroš, Marta Šavor}

Original scientific paper

\section{Influence of contact stresses on bearing capacity of traditional stone columns}

Traditional stone columns, built by linking the base, body of column and capital with a dowel in the column axis, are often characterized by typical cracks in connection zones that are continuously propagating. Despite numerous retrofit, this cracking can not be stopped, which points to an intrinsic defect. A systematic study involving a number of numerical models of variable complexity, and laboratory testing of quasi-real size samples, was initiated In order to determine the cause of the problem. Some results describing typical behaviour of columns are presented in the paper.

Key words:

eccentrically loaded connection, stress concentration, laboratory tests, numerical analysis

Izvorni znanstveni rad

Josip Atalić, Mario Uroš, Marta Šavor

\section{Utjecaj kontaktnih naprezanja na tradicijski kameni stup}

Tradicijski kameni stupovi, izvedeni spajanjem baze, tijela i kapitela trnom u osi stupa, često su prožeti karakterističnim pukotinama u blizini spojeva koje kontinuirano propagiraju. Brojnim sanacijama tijekom povijesti ne uspijeva se zaustaviti raspucavanje, što upućuje na neku suštinsku manjkavost. Radi utvrdivanja uzroka problema pokrenuto je sustavno istraživanje koje se temelji na nizu numeričkih modela različitih složenosti i laboratorijskom ispitivanju na gotovo realnim dimenzijama uzoraka. U ovom radu je prikazan dio rezultata koji opisuje karakteristično ponašanje stupova.

Ključne riječi:

ekscentrično opterećeni spoj, koncentracija naprezanja, laboratorijska ispitivanja, numeričke analize spojeva

Wissenschaftlicher Originalbeitrag

Josip Atalić, Mario Uroš, Marta Šavor

\section{Einfluss von Kontaktspannungen auf die Tragfähigkeit von traditionellen Steinsäulen}

Traditionelle Steinsäulen, ausgeführt durch die Verbindung der Base, des Körpers und des Kapitels mit einem Dorn in der Säulenachse, sind oft von ausgeprägten Rissen gekennzeichnet, die in der Nähe der Verbindungen entstehen und sich dauerhaft ausbreiten. Da mittels zahlreicher Sanierungen in der Vergangenheit die Rissbildung nicht verhindert werden konnte, ist auf einen wesentlichen Mangel zu schließen. Um die Ursache des Problems zu ermitteln, ist ein gezieltes Forschungsvorhaben eingeleitet worden, dass auf numerischen Modellen verschiedener Komplexität und Experimenten an Versuchsstücken in nahezu voller Größe beruht. In dieser Arbeit ist ein Teil der ermittelten Ergebnisse dargestellt, die das typische Verhalten der untersuchten Säulen beschreiben.

Schlüsselwörter:

exzentrisch belastete Verbindung, Spannungskonzentration, laboratory Versuche, numerische Analyse 


\section{Introduction}

Continuous problems with columns at the atrium of the Rector's Palace in Dubrovnik, where after numerous repairs the basic cause of the problem has not been discovered, nor has the cracking stopped, are a motive for new extensive studies, which are partly presented in this paper. Difficulties with these columns have been experienced on many occasions in the past as can be seen from old reports and notes [1]: "a part of the capital broke off during the 1968 Summer Festival" or "this is a part of the capital from the column near clack that was replaced in 1952" or "columns above the pedestal were successfully repaired in the past", while the most significant note is perhaps the following one: "damage to individual parts of double columns seems to be a continuous occurrence". Numerous remains from previous repairs can even now be observed in the palace: different types of stone, different styles and forms of capitals, hoops around columns (Figure 1.a), broken parts held together by wire (Figure 1.b), various inserts and voids filled with mortar, lead or wood (Figure 1.c), etc. It has been established during various studies that similar problems have also been encountered in other parts of Croatia (Veliki Tabor [2], Zadar, Split, Orebić (Figure 1.d), and throughout the world on well known cathedrals (Mexico City [3], Barcelona, Pavia, Beauvais, Mallorca and in many other localities).

Throughout the history, columns have often been the subject of repairs and were usually depicted as the weakest elements of the static system of historic buildings as their (sometimes exaggerated) slenderness was the axis of architectural expression. However, during these repairs the causes of cracking in the vicinity of contacts were regularly hidden by a number of other problems historic buildings are usually faced with. In addition, many famous buildings were additionally damaged by inappropriate repairs, because the essence of the problem was not recognized.

Time has revealed that these buildings require multidisciplinary approach that has to be based on contribution from a variety of completely different scientific disciplines [4] as a single profession can not be expected to successfully solve a great number of specific problems encountered in these buildings. For instance, the study of smaller cracks on walls and vaults is in most cases quite pointless as cracking is assumed to occur in such structural elements. However, cracks in columns can over time become quite critical as, unlike other parts of the structure, the load from connection points can not be released. Consequently, the analysis of details of historic buildings requires good knowledge of the essence of the static system, and so the role of the civil engineer must be more important than someone's mere conclusion that a big longitudinal force is responsible for crack formation in columns [5].

A detailed numerical and experimental analysis, partly described in this paper, has been undertaken in order to define the actual behaviour of traditional connections, and hence the causes behind crack formation. Such data are crucial for defining a correct approach to repair activities, and for developing more permanent solutions that will greatly postpone crack formation in columns. The whole study is therefore oriented toward development of an acceptable repair method.

\section{Problems with traditional stone columns}

In traditional building practices encountered in our region, we often find columns formed of shaft, base and capital, especially when a great slenderness is required, i.e. when the column height with respect to the base width exceeds the ratio of 15 [6]. Column elements are made of a single piece of stone and are in most cases linked tohether with an iron peg placed in openings of a larger diameter (subsequently filled with lead). These openings are usually situated at the center of the column, while sometimes an alternative invoving connection with two or three regularly distributed pegs is also encountered. It has been established by detailed analysis of connection faces that they have been carefully flattened and joined together, which is in accordance with principles applied in construction of historic buildings, according to which the described connection should assume the centric compressive load without any difficulty. However, this connection is not destined for assuming a significant eccentric load as can be seen from properties of
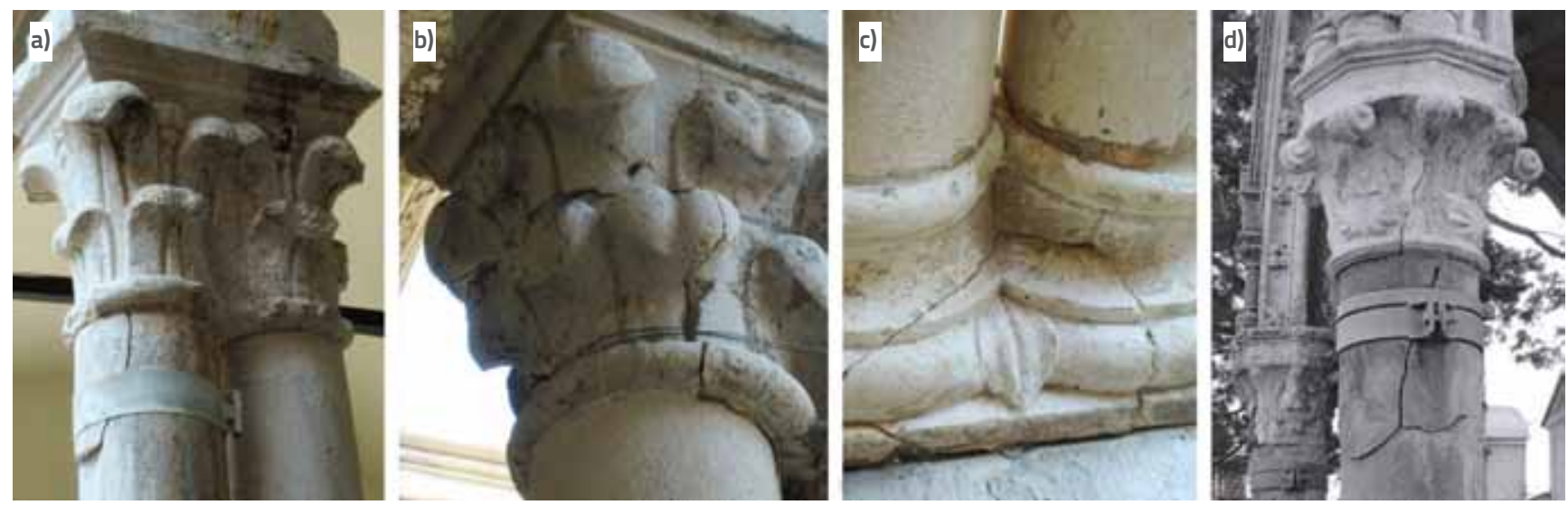

Figure 1. Cracking on traditional stone columns with remains of previous repair work 
details such as the centically place peg in the column acis and poor oanchouring into the stone (Figure 2.a) [7]. a)

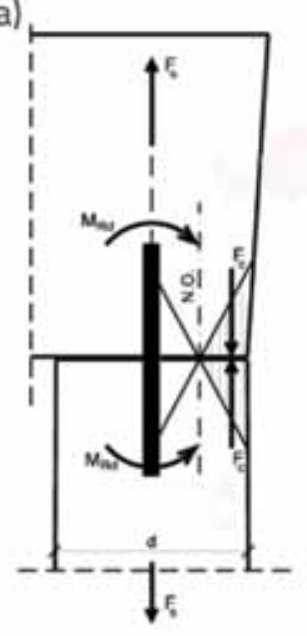

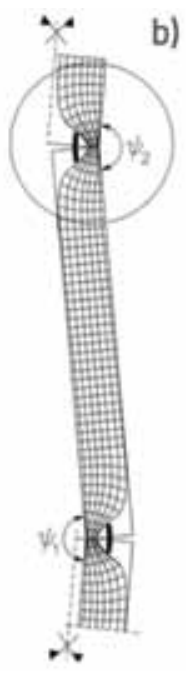

b)

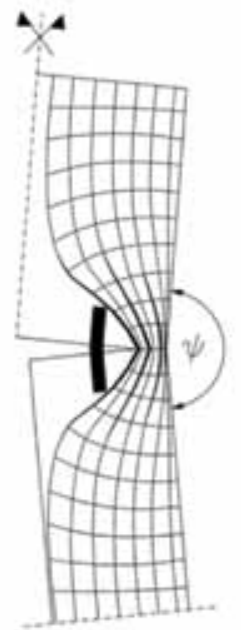

Figure 2. Connection behaviour model: a) internal forces and stress, b) distribution of stress trajectories [8]

Unfortunately, imperfections during realization, uneven settlement of foundations, earthquakes, stress redistribution in vaults, temperature, and numerous interventions during the life span, cause eccentric load and deviation of columns from the vertical axis. Even at very small deviations the connection elements turn, i.e. the connection opens on one side and contact surfaces are joined on the other side of the cross section. As the contact surface (compression zone) is extremely small (theoretically infinitely small), the occurrence of big boundary compressive stresses becomes inevitable. These stresses result in the opening of typical joints in the vicinity of contacts. The described behaviour is in accordance with the distribution of stress trajectories as it is obvious that the pronounced concentration of compressive trajectories leads to fracturing of material at the edges (Figure 2.b), while the big distortion of perpendicular tensile trajectories causes significant resulting turning tensile forces which, due to small tensile strength of the stone, cause opening of longitudinal joints (stone splitting) [7].

The area affected by cracking is very sensitive to changes of temperature, moveable load and, primarily, to changes in differential settlement or earthquakes. The corrosion (activated by the split state enabling penetration of moisture) is especially harmful as it results in peg swelling and in an increase in tensile forces. These effects cause a constant activation of cracks, which eventually leads to their progressive extension [8].

The described problem has often remained undetected as stress trajectories become parallel in zones not close to contacts (Figure 2.b) and measurements reveal low level of stress in columns, i.e. a high safety coefficient (which is in most cases greater than 10 [9]). Investigations have shown that the knowledge of properties or behaviour of contacts is indispensible for a reliable estimation of stress distribution in the structure and for a more accurate estimation of safety coefficients.

\section{Numerical approach to the problem}

During numerical analyses, it is important to bear in mind the fact that historic buildings were most often built according to verified rules about relationships between structural elements (Vitruvius [10]). In best cases, they were analyzed using approximate graphical methods or the compressiontension analogy [9]. However, these procedures can not take into account sensitive behaviour of a specific detail such as the contact. For instance, deviations from the vertical axis of less than one centimetre are sufficient for crack opening [11], which is still less than the thickness of a pencil in some real drawing scale of historic buildings.

A similar problem is present even today because, in addition to all modern day tools and aids, researchers most often
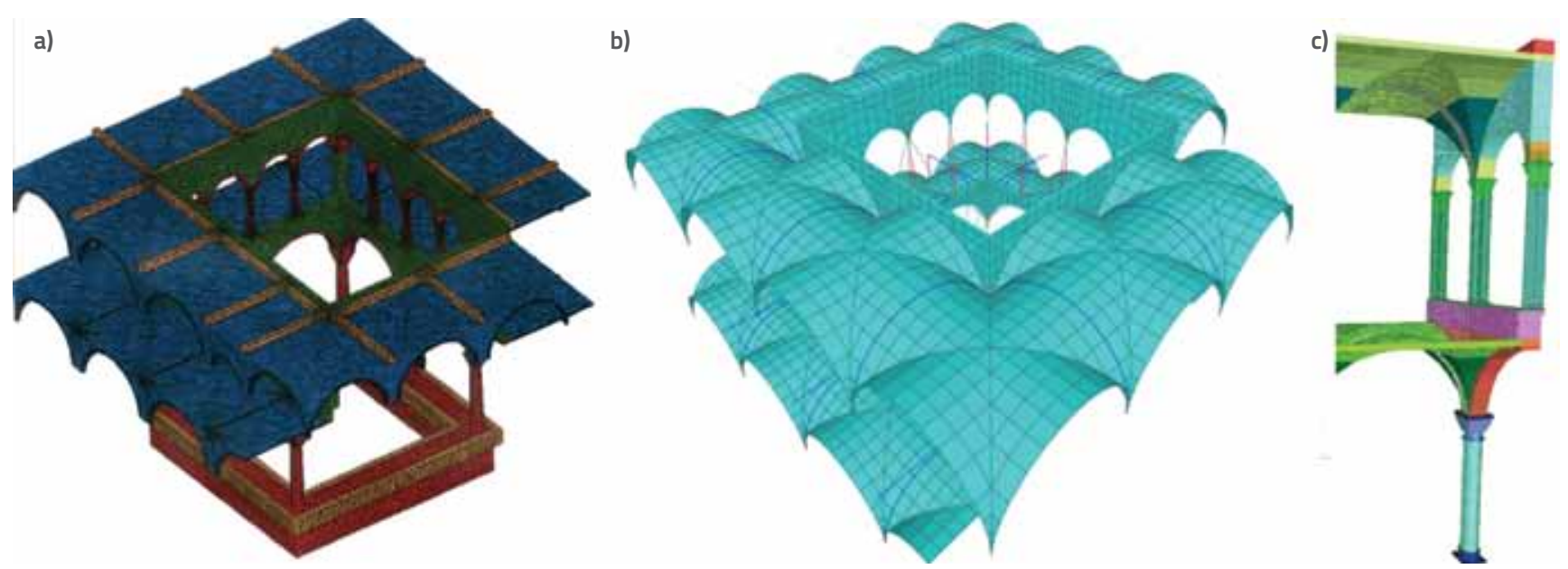

Figure 3. Numerical models of the Rector's Palace: a) by volume elements; b) by bar and plate elements; c) detailed model of a typical part [16] 


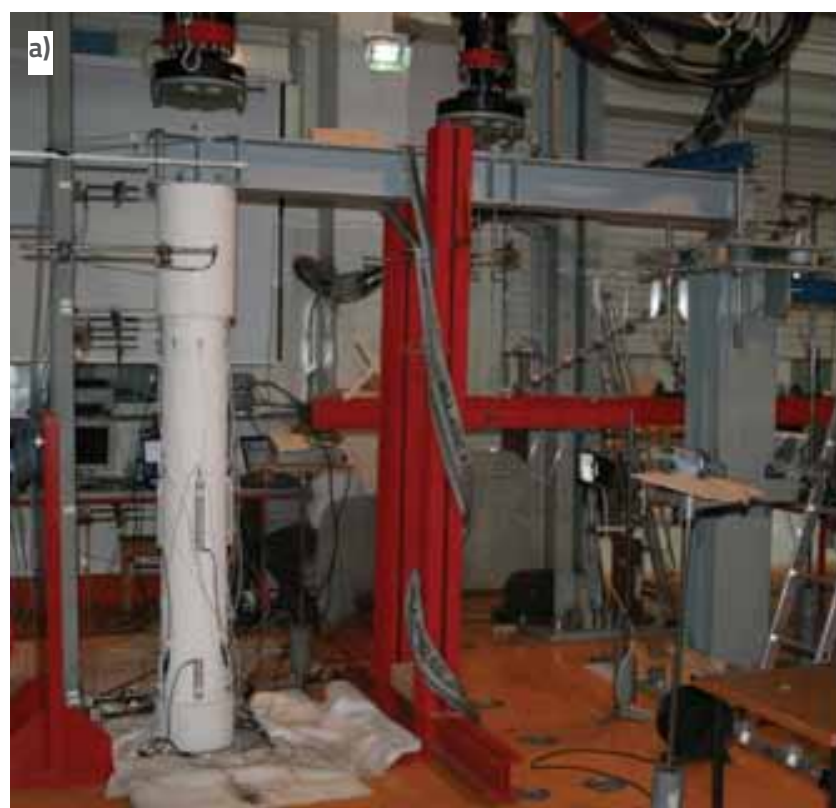

Figure 4. Testing assumption for the sample K2 (stone sample 2)

create (sometimes even highly sophisticated) global structural modesl in which it is still very hard to take into account a highly complex behaviour of individual details. The model of behaviour of contacts, primarily in post-critical phases, can not easily be described without experimental results. It is known that destructive test methods are unacceptable in case of historic buildings [4] and so uncritical use is often made of complex nonlinear analyses, which depend a multitude of unreliable input parameters. On top of that, problems related to historic buildings (static system determination, poor knowledge of properties of materials built into the building, existence of hidden cracks, unknown inherited state of stress and strain, disturbed original condition of the building e.g. by subsequent additions or changes in occupancy, insufficient or inexistent documentation, etc.) show that the preparation of numerical models and interpretation of results require an immense level of knowledge and extensive experience, and also a certain level of lucidity. Nevertheless, despite many aggravating circumstances, numerical analyses play an increasingly important role in the study of behaviour of historic structures and, if properly used, they can facilitate the task of the researchers.

At any rate, it should be noted that numerical analyses have played a dominant role in discovering weaknesses of contacts subjected to eccentric loads, and the most significant progress in present day research has been made with the numerical model of the atrium of the Rector's Palace in Dubrovnik (Figure 3.a) using the program package FEAP 7.4 [12] and GID 6.1.2a [13]. The program has been complemented with original routines for exclusion of the finite element if the strength is exceeded, which has resulted in better description of behaviour in the vicinity of contacts [14]. The mentioned research has defined the nature of the problem, and this
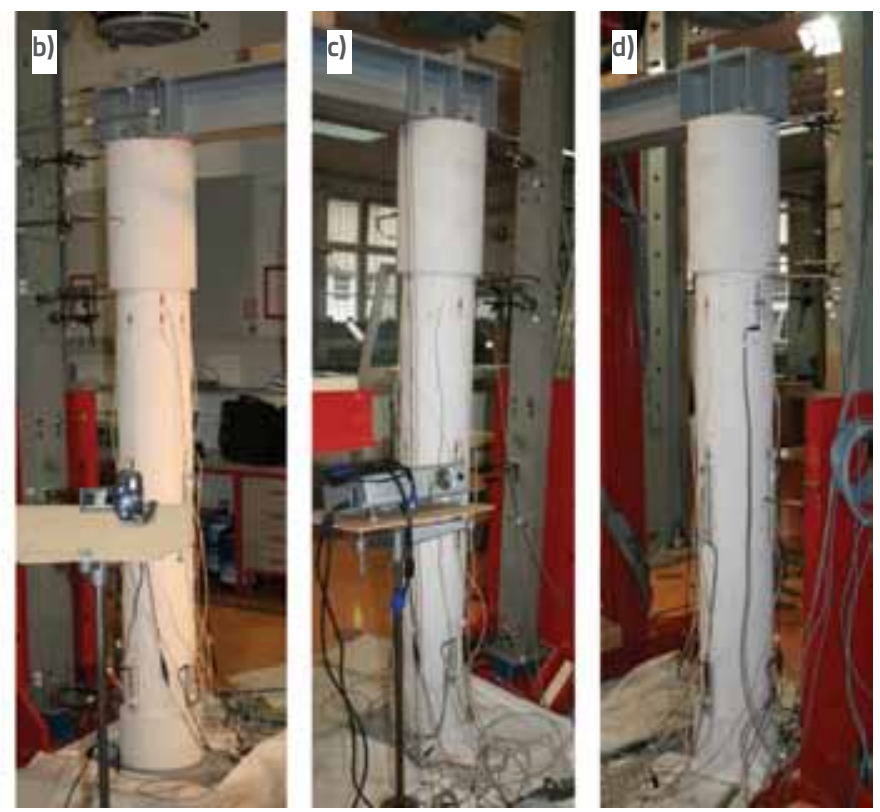

research directly relies on conclusions made with the focus on a more detailed approach to contact zones.

All analyses conducted in this research were made by means of the program package SAP2000 [15] which was selected based on the availability of input data and planned algorithms, taking into account all of the above mentioned restrictions. During the research numerous numerical models with different levels of complexity were made, and the laboratory testing model, which will be described in more detail in the following text, was selected for this paper (Figure 7). It is significant to note that contact behaviour was successfully described by adjusting integrated SAP elements to available laboratory testing results and numerous sensitivity tests. Parameters checked in full detail enabled creation of goodquality models of the contact zone, and were then used in the global model such as the one for the Rector's Palace, based on bar and plate elements (Figure 3.b), where the contact behaviour was defined by rotational stiffness of spring to bending action [7]. Finally, it is important to point out that the results of analyses made at the model of a typical part of the Rector's Palace (Figure 3.c) undoubtedly prove that models that do not contain a detailed approach to contacts can greatly underestimate the building's safety coefficient [11], as will be confirmed through laboratory testing.

\section{Laboratory testing assumptions}

Laboratory tests of column samples are the very essence of this paper and they constitute the only way to reliably prove all assumptions and results obtained through numerical computations. Attempts were made to obtain test samples from the quarry situated on the Vrnik Island (near Korčula) as this stone was initially used in the construction of the 
Rector's Palace columns as well as in construction of many parts of the old town of Dubrovnik. However, the quarry is now administratively closed and so the Korunito stone from the neighbouring Piska Quarry on the Korčula Island was accepted as a replacement solution. As the problem of column behaviour at contact zone has been registered all over Croatia (and all over the world), it can reasonably be stated that stone properties are not crucial for the resolution of the problem. Nevertheless, due to initial cracking that was observed during extraction of stone samples, a special care was paid to the depth and orientation of layers and, at that, zones with visible traces of water or damage were avoided. The final treatment of samples was made in a traditional way, except for contact surfaces that were cut by machine so as to enable the best possible contact between column elements. Mechanical properties of stone were determined experimentally by testing compressive and tensile strength and elastic modulus, while fracture mechanics parameters were subsequently included in the testing [11].

The testing procedure that closely simulates the behaviour of existing structures was defined (Figure 4). The initially planned alternative with arches or vaults was rejected as it can not be applied for laboratory testing of a set of samples until failure. The solution with horizontally placed steel beam (HEB200 with reinforcements) for load application was obtained after extensive numerical simulations. This solution ensures a good distribution of stresses along the column, controlled application of force, simple assembly, almost fullscale sample dimensions, and safety at cracking. The steel beam was specially adapted for the application of load using the universal compression/tension machine Zwick/Roell with pistons. The main piston with the capacity of $\pm 600 \mathrm{kN}$ was placed on the beam above the column (centrically), while the $250 \mathrm{kN}$ piston was placed in the middle of the steel beam span (eccentrically). The pistons can apply load via a force or displacement control, and can monitor the post-critical behaviour of the contact zone, which is crucial for determining the bearing capacity reserve at cracking. During the testing, the force was applied by displacement control, and the increments of $0.01 \mathrm{~mm} / \mathrm{s}$ were used.

Steel beam dimensions $(\mathrm{l}=2.4 \mathrm{~m})$ were selected so as to enable controlled bending (deformation) of the beam in an elastic area through application of load in the middle of the span. The angle of beam rotation above the column is transferred onto the capital via the contact with screws in epoxy resin, by which we obtained the desired contact between the capital and one side of the column cross-section. On the other side, the beam leaned onto a separate structure that simulates the fixed bearing of a historic building. Column sample dimensions were selected in accordance with dimensions of double columns situated at the first floor of the Rector's Palace in Dubrovnik. The capital $(300 \mathrm{~mm}$ in diameter and $500 \mathrm{~mm}$ in height) was placed onto the column ( $d=250 \mathrm{~mm}, \mathrm{~h}=1500$ $\mathrm{mm})$, and they were linked together with a steel peg ( $\mathrm{d}=16$ $\mathrm{mm}, \mathrm{h}=150 \mathrm{~mm}$ ) placed in openings ( $\mathrm{d}=19 \mathrm{~mm}, \mathrm{~h}=100 \mathrm{~mm}$ ) located in the centre of the cross section. The same method was used to link the column with the base $(\mathrm{d}=300 \mathrm{~mm}, \mathrm{~h}=\mathbf{2 0 0}$ $\mathrm{mm}$ ) which lies on the steel support which was adequately strengthened to prevent sliding.

Compared to the columns at the Rector's Palace, the sample height is one half of the real height which, according to distribution of stress trajectories, has no influence on real behaviour and required distribution of stresses. The capital height was slightly increased so as to avoid possible influence of screws by which the capital was attached to the steel beam. In test samples, the lead was not poured around the peg, and the elements are devoid of decorative details typical for historic buildings, as they are of no consequence for contact stresses. In addition, the analysis of influence of various inserts that can be found in between the contacts faces has been left for subsequent phases of the research.

The initial testing assumption contained Measurement Points (MM) for displacement and relative strain measurements. These points were defined based on numerical simulation results. All displacements were measured using linear variable differential transformers (LVDT) with different bases, depending on expected displacement values (Figure 4.a). The deformation in mid span and angle of rotation above the capital were measured on the steel beam, while piston forces and displacements were registered at the compression machine. The capital rotation angle was monitored by measuring horizontal displacements at the top and bottom of the capital, and the angle obtained was compliant with the angle of rotation of the steel beam above the column, which confirms the fixity of the contact. An additional control was enabled by placing the MM at the column shaft (Figure 4.d), and by measuring the capital uplift value, which confirmed the existence of the required contact at the opposite side of the cross section. Horizontal displacements were measured along the column shaft height: at the top, in the middle and at the bottom of the column, and especially near the base so as to check for possible sliding along the steel support.

The stress distribution in column was obtained by measuring relative deformations using inductive transformers (LVDT) and (or) strain gauges placed along the perimeter of the column shaft. Measurement points were divided into three groups along the column height and were marked according to this arrangement: column top (VS), column centre (SS) and column bottom (DS). Distribution of measurement points within individual groups was defined according to expected stress distribution values, and it varied depending on the sample. Although more modern measurement procedures that directly measure stress between contact faces are currently available, they were not used because the position of the device would in that case disturb the local state of stress, and the results would directly be affected.

Before the actual stone sample testing, preliminary tests were conducted on similar concrete samples in order to 


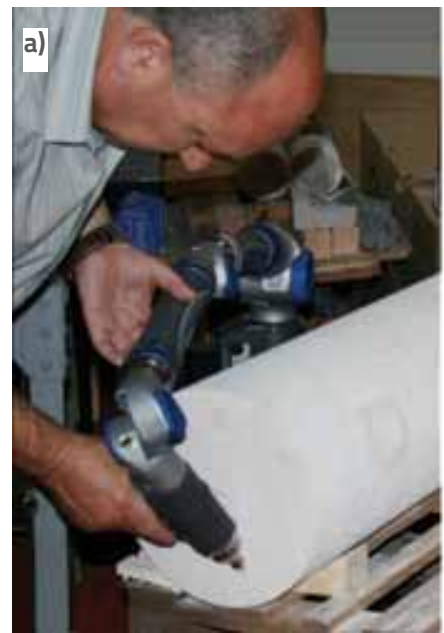

b)

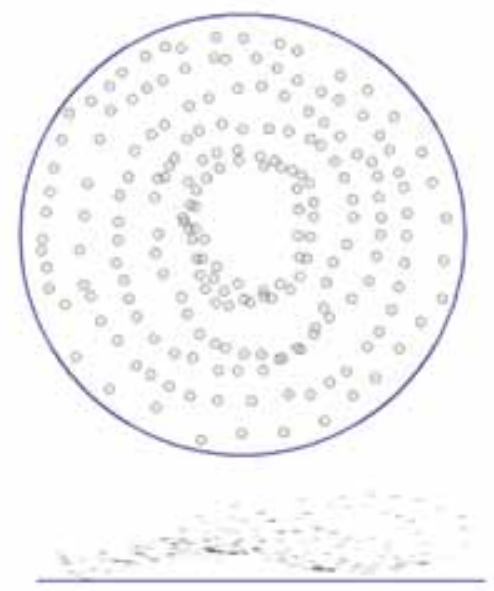

c)
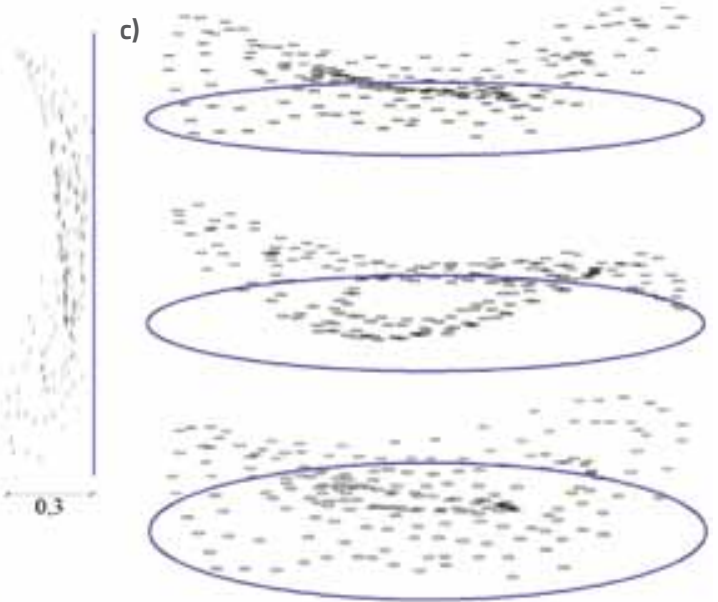

0.3

Figure 5. Determining shape of contact faces: a) measurement by FaroArm device; b) in plane presentation of measurement points; c) spatial presentation of measurement points [16]

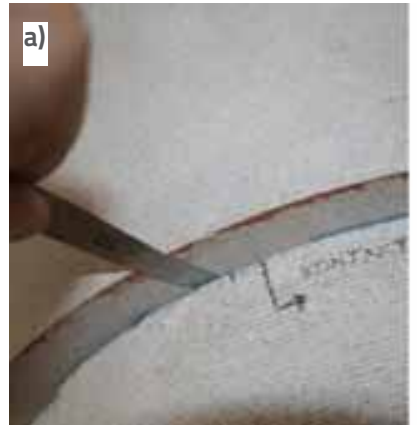

b)

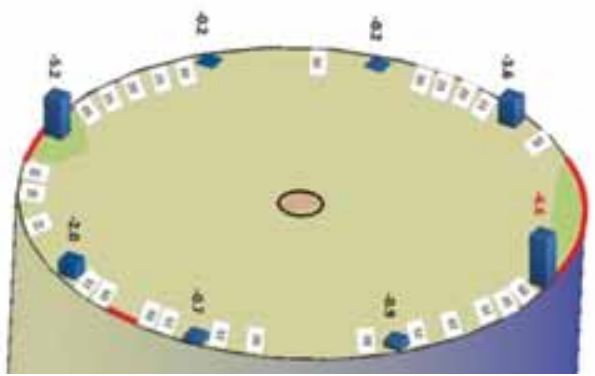

c)

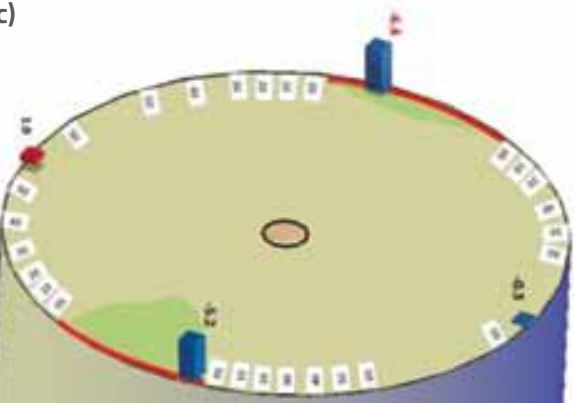

Figure 6. Test phase of investigations (sample K4): a) deviation measurement by measurement sheets; b) stress values at VS; c) stress vaues at DS

improve initial test assumptions and to make adjustments when necessary. The most significant improvement is the notable densification of points (MM) for measuring relative deformation with respect to initial distribution, and a gradual replacement of LVDT with strain gauges, which have proven to be a better solution. Displacement measurements were complemented with $\mathrm{MM}$ for the control of displacement outside of the experiment plane, and with additional MM in the steel beam mid span, which enabled beam torsion calculations. The testing assumptions were improved with every new sample, and the column behaviour at centric and eccentric load was always successfully determined, as will be shown below on an example of two test samples.

\section{Laboratory test results}

\subsection{Testing phase}

The laboratory testing of all samples started by application of the $100 \mathrm{kN}$ centric load with piston positioned above the column (testing phase) for which an uniform distribution of about 2.0 MPa along the cross section was expected, based on initial assumptions and results obtained by preliminary numerical calculations. However, despite very stringent laboratory conditions, careful extraction and accurate treatment of samples, the results obtained pointed to very uneven distribution of stress values (for all samples subjected to testing). We were therefore forced to introduce new measurements that would assist us in the interpretation of results. It was finally established through determination of deviation of contact faces from the plane using the FaroArm device [17] (accuracy: $2 / 100 \mathrm{~mm}$ ) that some slight unevennesses (of less than $0.5 \mathrm{~mm}$ ) exist at contact faces, and that these unevennesses are sufficient to prevent ideal contact or uniform distribution of stress vales (Figure 5). In addition, due to these unevennesses, the measurement of deviation between contact faces via measurement sheets (Figure 6.a) was subsequently introduced. This measurement was conducted immediately before the start of the testing.

Measured deviations enabled good interpretation of the uneven stress distribution obtained by testing, as can be seen on the results of the sample $\mathrm{K} 4$ test phase (Figures 6.b and 6.c). In these Figures, the contact between column elements is marked with red line, while deviation values $(1 / 100 \mathrm{~mm})$ are inserted in between. The three-dimensional schematic presentation of stress results obtained by relative deformation measurements was selected, as it also shows stress relationship in which compression stress is marked in blue, while the tensile stress is marked in red. 

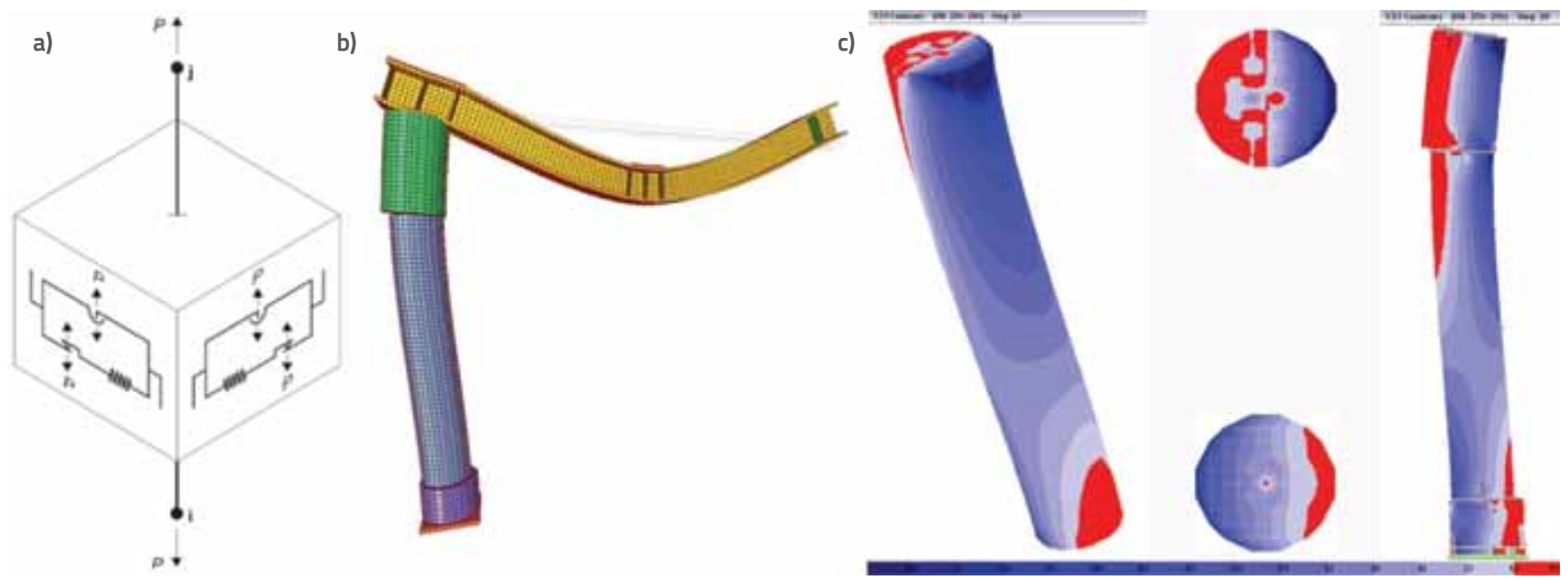

Figure 7. a) Material model of connection elements; b) Numerical model of the testing - deformed state at eccentric load; c) Stress distribution along the column shaft, contact faces and in the vertical cross section through the axis [5]

The influence of contact face unevennesses can be estimated if maximum stress concentration values (about $6.6 \mathrm{MPa}$ ) are compared with an average stress that would have been obtained if an uniform distribution along the cross section were assumed (2.0 MPa). On top of that, it should be noted that $\mathrm{MM}$ were placed $10 \mathrm{~cm}$ away from contact faces, and so the values presented also include stress distribution from the concentration zone on contact faces to measurements points placed $10 \mathrm{~cm}$ away from the edge of the element (at the perimeter of the column shaft). We used numerical models in order to get closer to real stress values on contact faces (that are about three times as great). Models were calibrated based on experimental results and they provide stress distribution along the entire sample, as well as a good estimate of the area of contact between the contact faces, as shown in Figure 6 (marked in green). Unevennesses of contact faces are a new parameter discovered during the testing, and it directly affects eccentric load. This is why we will try to examine more closely their joint influence on the bearing capacity of the column using two typical samples as an example.

\subsection{Numerical model of laboratory tests}

The development of numerical model of laboratory tests was initiated during definition of experimental assumptions, and it was used to check the progress of testing, to interpret the results and, finally, to calibrate global models of structures. The stone sample, i.e. the capital, column and base, were fully modelled by volume elements (Figure 7.b), while the peg and screws for connection with the steel beam were modelled by bar elements and, at that, the peg was defined as a compression element only. For the purposes of contact stress analysis, the steel beam was modelled with volume elements in the same way as the strengthenings assuming the load, while only the sheet metal for steel beam strengthening was defined with plate elements.
The principal objective of the model is to define behaviour of the contact itself, i.e. the occurrences on contacts faces and, in order to fulfil this objective, a relative rotation between column elements had to be ensured, i.e. the application of pressure on one side of the cross section. The described behaviour is non-linear, and it is defined by adjustment of integrated elements of the link between model nodes through definition of compression links only [15]. Considering the problem of deviations between contact faces, the deviation values were subsequently included and measured, which also brought us closer to the real behaviour of the connection. Together with the defined friction (for transverse directions), these carefully tested parameters are crucial for the definition of behaviour models for connections between column elements. All other degrees of freedom between nodes are connected with linear links. The theoretical basis is founded on hysteretic behaviour (Figure 7.a) proposed by Wen (1976) and also by Park, Wen and Ang (1986), as additionally complemented by Nagarajaiah, Reinhorn and Constantinou [15].

The load applied by pistons (centrically and eccentrically) is defined in the model with concentrated forces and, according to the planned loading regimen, the load was defined in phases. All loads also contain the P-d effect. One of basic objectives of the research is to analyze influence of eccentric load, i.e. the deviation of columns from the vertical axis. Typical results at usual centric and eccentric load values are presented as an illustration, although deviations between contact faces were not defined for this example, as these deviations are dependent on the specimen itself. In addition to deformed state (Figure 7.b) in which individual instances of separation of contact faces are visible, the typical stress distribution (Figure 7.c) caused by pressure applied by capital at the edge of the column is also presented. The longitudinal (vertical) stress component, also obtained from laboratory test results, is selected for this presentation. The compressive stress level is presented in nuances of blue colour, while tensile stress 
a)

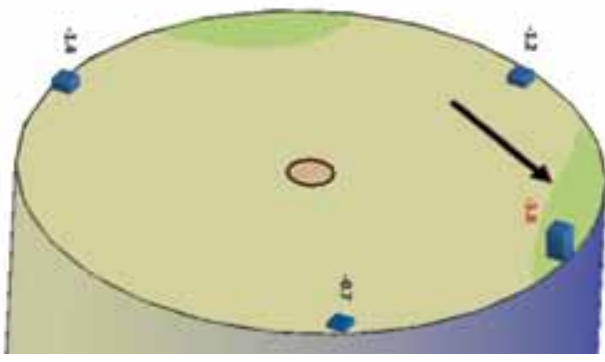

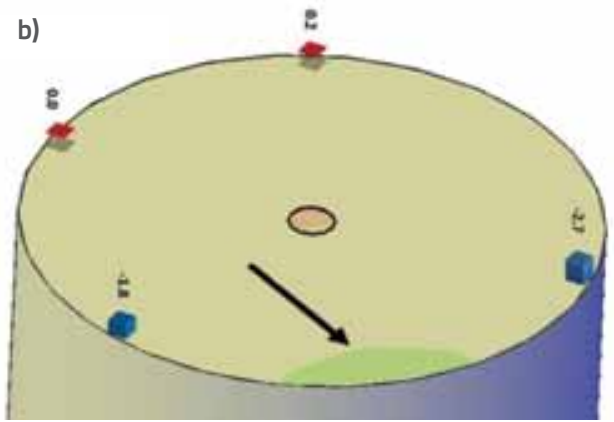

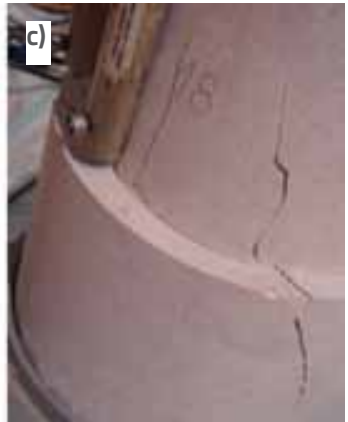

Figure 8. Test phase of investigations (sample K1): stress values at VS; b) stress values at DS; c) occurrence of first visible crack

values are presented in red, which is also in accordance with presentation of laboratory testing results. The results confirm the assumed concentration of compressive trajectories at the edge of the cross section (darker nuance of blue) and great distortion of the corresponding tensile trajectories that are responsible for crack opening (splitting).

The already mentioned distribution of stress, from the concentration zone at contact faces to measurement points, can be observed. This distribution confirms that accurate stress concentration values can not be obtained from relative deformation measurements. However, a reliable extrapolation can be obtained by means of well calibrated numerical models. Finally, results obtained by numerical models, with volume elements and link elements for description of connections, undoubtedly confirm that highly detailed models must be established to obtain a realistic description of behaviour at contact zones.

\subsection{Influence of contact face unevennesses on the bearing capacity of columns}

The influence of unevennesses of contact faces on the bearing capacity of traditional columns will be described using the sample $\mathrm{K} 1$ as an example. The sample was tested based on initial test assumptions that include measurement of relative deformations using only four LVDT per cross section, although such measurements can also be sufficient if combined with numerical models. This fact is important for measurement on real-life structures as it enables a good estimate of critical points even without group testing. For instance, even the test phase results are sufficient for estimating critical points, i.e. the points of application of pressure at contact faces (marked in green) for VS (Figure 8.a) and DS (Figure 8.b).

These assumptions were confirmed after the centric force was increased to $297.6 \mathrm{kN}$ when the crack occurred (Figure 8.c) near the marked place of application of pressure at DS (Figure 8.b). The analysis of results for all MM, immediately before and after crack opening, has revealed the redistribution of stresses or, in other words, the sample has established a new state of balance. This has been confirmed by continued testing when, depending of the newly realized contact, the unloading or increase of stress can be observed at individual MM. By further increase of centric force until $450 \mathrm{kN}$ a crack opened at VS. This crack also corresponds to initial stress concentration from the test phase (Figure 8.a). Just like during the opening of the first crack, the instantaneous change in stress, i.e. new stress distribution, was observed at almost all MM.

At the centric force of $500 \mathrm{kN}$, the contact zone between the column shaft and capital (VS) is already pervaded with cracks (Figure 9.a) and the crack opened at the base has spread high into the shaft of the column (Figure 9.b). The centric force of $500 \mathrm{kN}$ represents only $11 \%$ of the ideal bearing capacity (bearing capacity of an ideal cross section subjected to centric pressure, assuming an uniform distribution of stress) which corresponds to the assumed usability of traditional stone
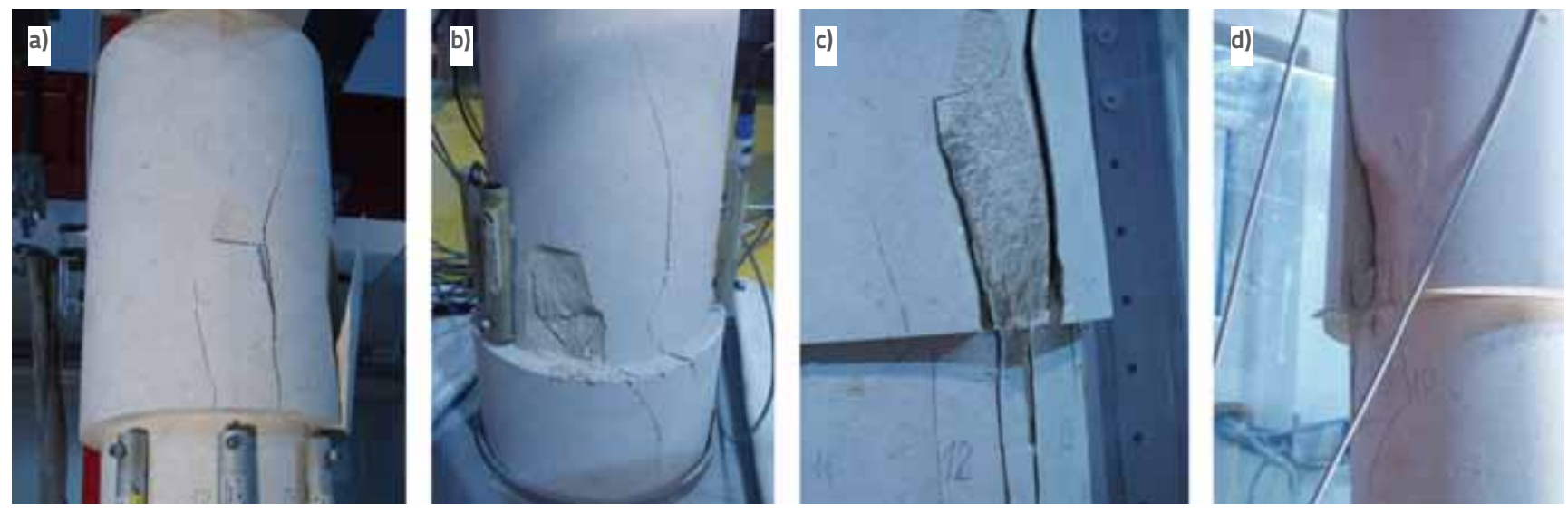

Figure 9. Cracked condition of sample K1: a) and b) VS and DS at centric force of $500 \mathrm{kN}$; c) and d) VS at centricl force of $500 \mathrm{kN}$ and eccentric force of $21.4 \mathrm{kN}$ 

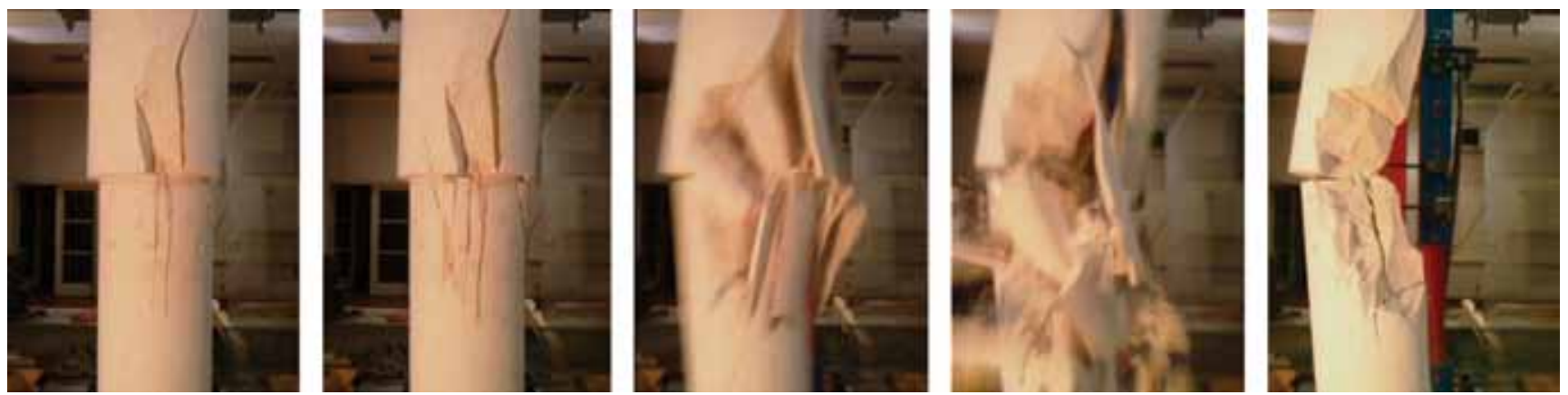

Figure 10. Splitting of sample K1 (VS) in the last phase of testing
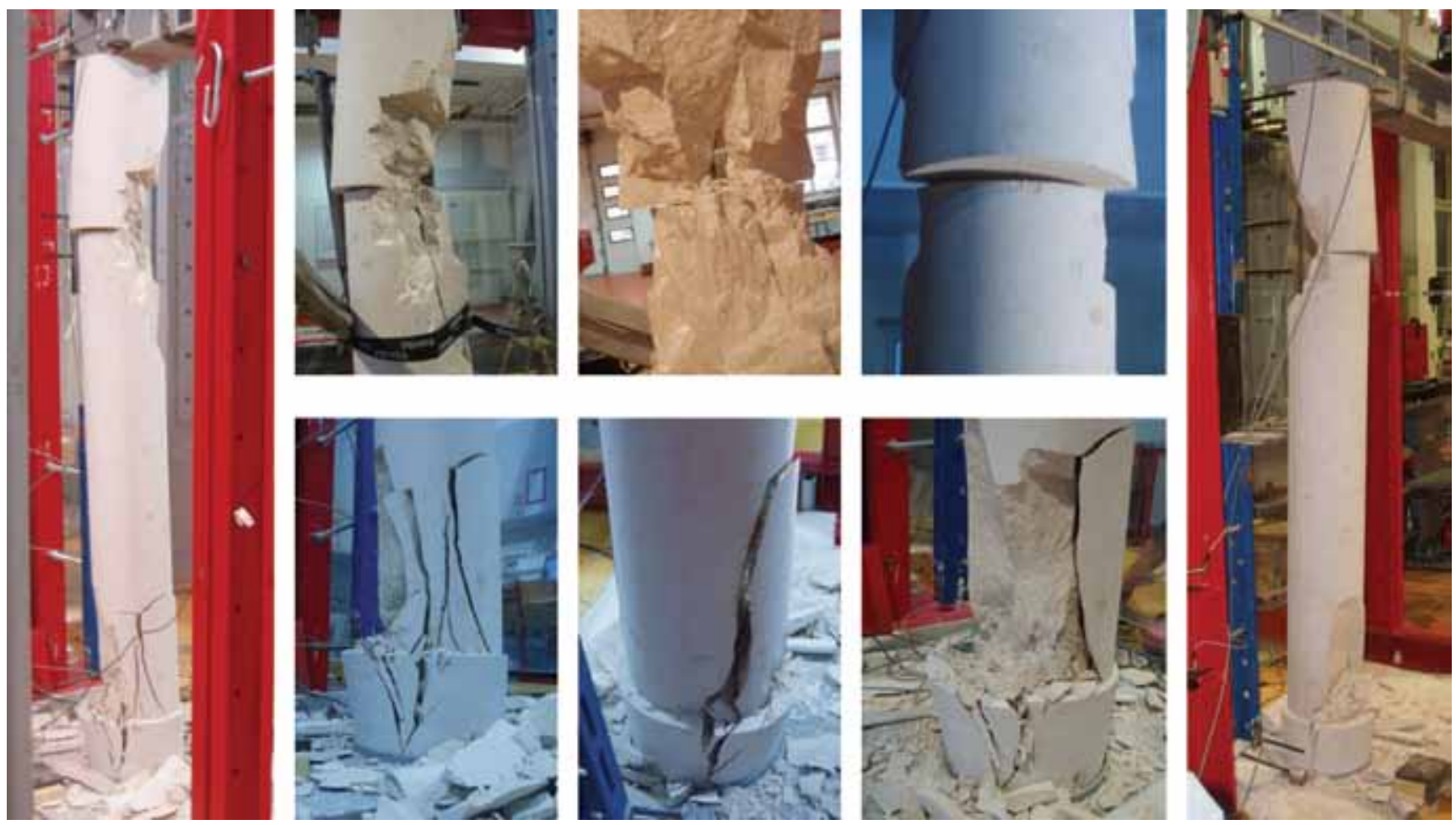

Figure 11. Sample K1 after failure [18]

columns which, according to literature, stands at about $10 \%$ [9]. At this stage, the column maintains its bearing capacity although some load change cycles attributable to historic buildings will cause propagation of cracks, dangerous detachment of column elements and, ultimately, a complete collapse. In a real-life building, a column cracked to such extent should urgently be repaired or replaced. It is favourable that, even after crack opening, a sufficient rest surface was found within the cross section, which enabled stress redistribution and prevented loss of bearing capacity.

According to testing objectives defined in advance, in the next phase, the sample was subjected to eccentric load by means of the piston placed in the centre of the steel beam and thus the capital pressure was moved to the edge of the column. As could have been expected, even a negligible eccentric load of $21.4 \mathrm{kN}$ caused a significant cracking at the capital level (Figures 9.c and 9.d) but, due to redistribution of stresses, the sample retained its load bearing capacity. The testing was then resumed and, with a continuous piercing sound of crack propagation, the full sample splitting and failure occurred at the eccentric force of $140 \mathrm{kN}$ (Figure 10).

During disassembly of the cracked sample, it was noted that the propagation of the first crack is clearly visible. New cracks that opened in the immediate vicinity of the first one due to redistribution of stress were also visible (Figure 11). The situation is similar at the contact between the column shaft and capital, but here the cracking is more pronounced due to greater influence of eccentric load.

This has been a brief presentation of typical behaviour of the first test sample $K 1$, with an emphasis on the influence of unevennesses of contact faces on the bearing capacity of a traditional stone column. It is obvious that initial deviations during element positioning can be overcome only through deformation of unevennesses in the contact zone, which eventually leads to 
a)

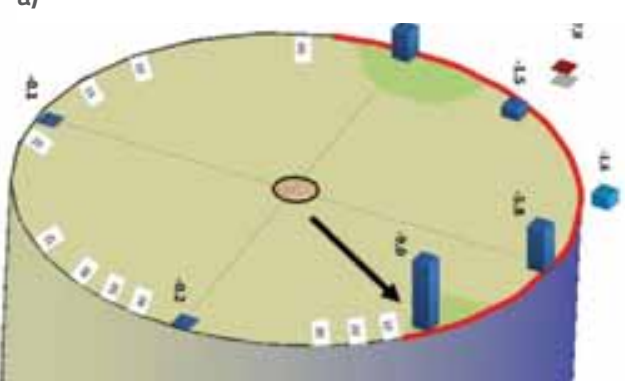

b)

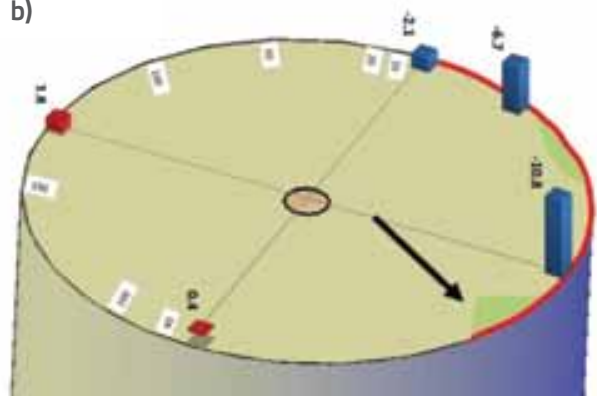

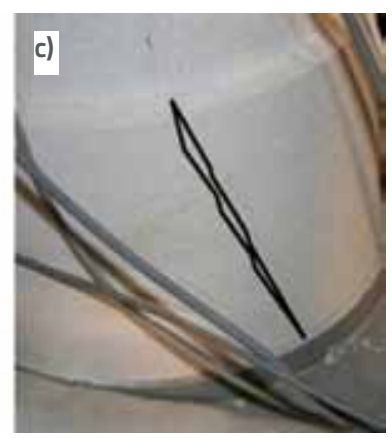

Figure 12. a) and b) Stress distribution in test phase of investigations for VS and DS (sample K3); c) First visible crack at the column base
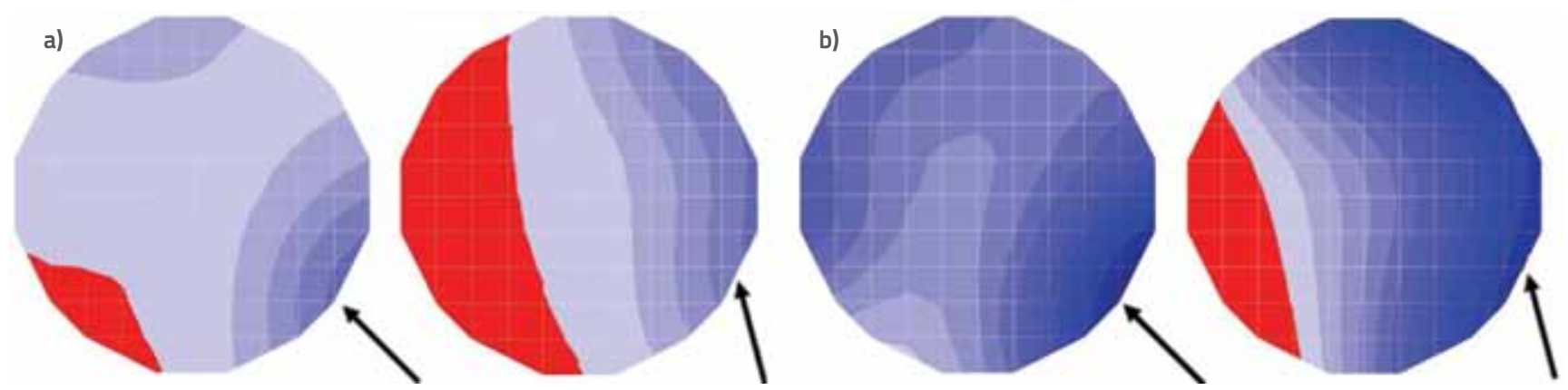

Figure 13. Redistribution of normal stress values at MM: a) 100 kN centric load (test) - VS and DS; b) 500 kN centric load - VS and DS [5]

crack opening. By redistribution of stress the column retains its bearing capacity until the full failure of the cross section, but the cracking becomes dangerous much earlier due to possible detachment of individual elements of the column.

\subsection{Influence of eccentric load on bearing capacity of the column}

The influence of eccentric load on the bearing capacity of the column will be described using the sample $\mathrm{K} 3$ as an example. Unlike the previous testing, the loading regimen with an emphasis on eccentric load is applied. Deviations at the column element positioning are accurately determined before the testing, and MM for relative deformation measurements are distributed in accordance with the predefined positioning plan. Compared to the previously described sample, the number of MM points has increased and strain gauges are mostly used instead LVDT's as they provide more reliable results. This sample is characterized by the use of additional MM closer to contact faces (at $4 \mathrm{~cm}$ - Figure 14.c), which has enabled a more accurate calibration of numerical models.

A detailed preparation for the testing has enabled a good interpretation of stress distribution within the sample and an accurate determination of critical points already at the test phase, i.e. at the centric load of $100 \mathrm{kN}$ (Figures 12.a and 12.b). A good calibration of numerical models (especially as to deviations between contact faces) is crucial for the interpretation of results as the marked maximum stress values of 9.0 MPa for VS and 10.7 MPa for DS were obtained in $\mathrm{MM}$ positioned $10 \mathrm{~cm}$ away from the contact face. In addition, the position of MM does not have to correspond to the position of the maximum concentration of stress. For instance, the position of stress concentration for DS (Figure 12.b - marked in green) is not located immediately below the MM. It is obvious that stress distributions obtained by numerical models (Figure 13.a) and laboratory testing (Figures 12.a and 12.b) correspond to each other. However, the importance of numerical calculations lies in the fact that they provide data about stress distribution in the entire sample, while extrapolation of stress onto contact faces is especially significant. Thus, according to numerical calculations for the critical position in DS, the stress concentration at the contact face greatly exceeds 10.8 MPa which has also been confirmed in the course of subsequent testing. The slight increase of centric force to $137 \mathrm{kN}$ resulted in the opening of the first visible crack (Figure 12.c) in the vicinity of the marked stress concentration (Figure 12.b).

Results for almost all MM show the opening of cracks and the instantaneous redistribution of stress at contact faces, i.e. a new positioning between the column shaft and the base. According to stress distribution prior to and after the crack opening, and based on stress increase in the course of subsequent testing, it can be concluded that the column shaft lies on the base on both sides of the crack.

The testing was continued until the centric force of $200 \mathrm{kN}$ which is in accordance with force values obtained in double columns (Figure 1.a) of the Rector's Palace in Dubrovnik [7]. If the state of sample is analyzed for the force representing 

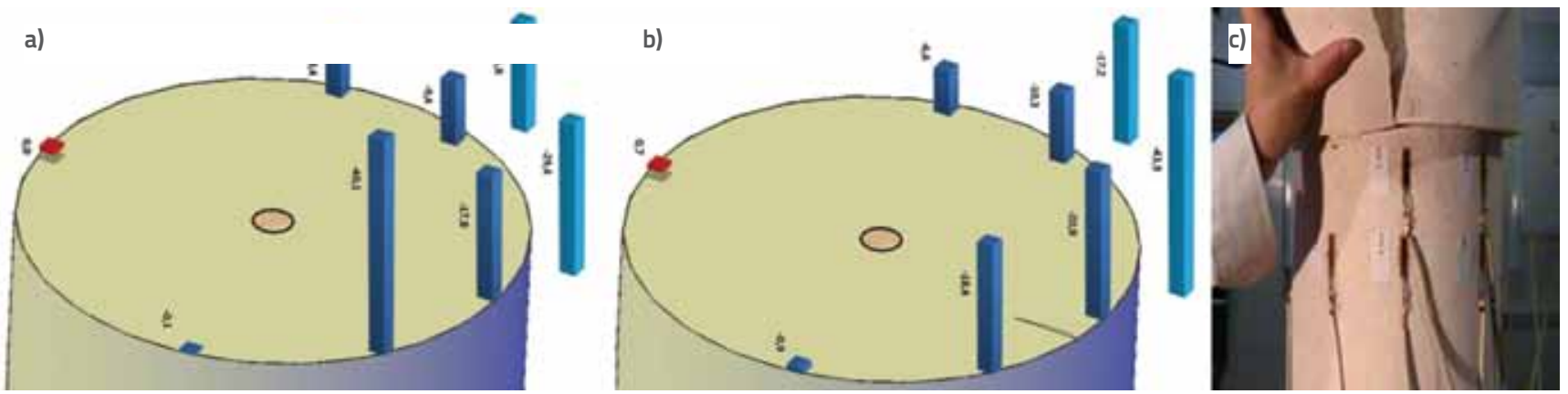

Figure 14. a) and b) Distribution of stress prior to and after crack opening at VS (sample K3); c) crack in capital (VS)
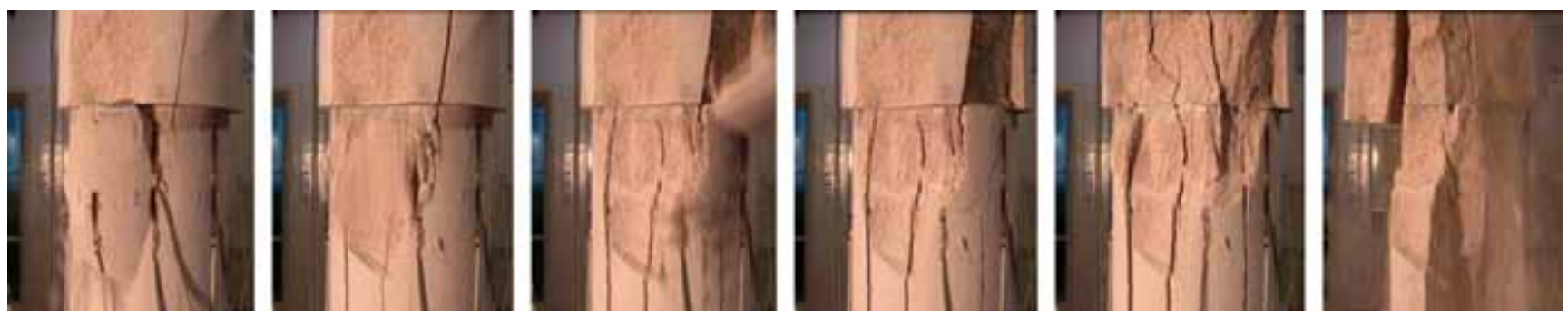

Figure 15. Sample K3 splitting until failure (VS) [5]
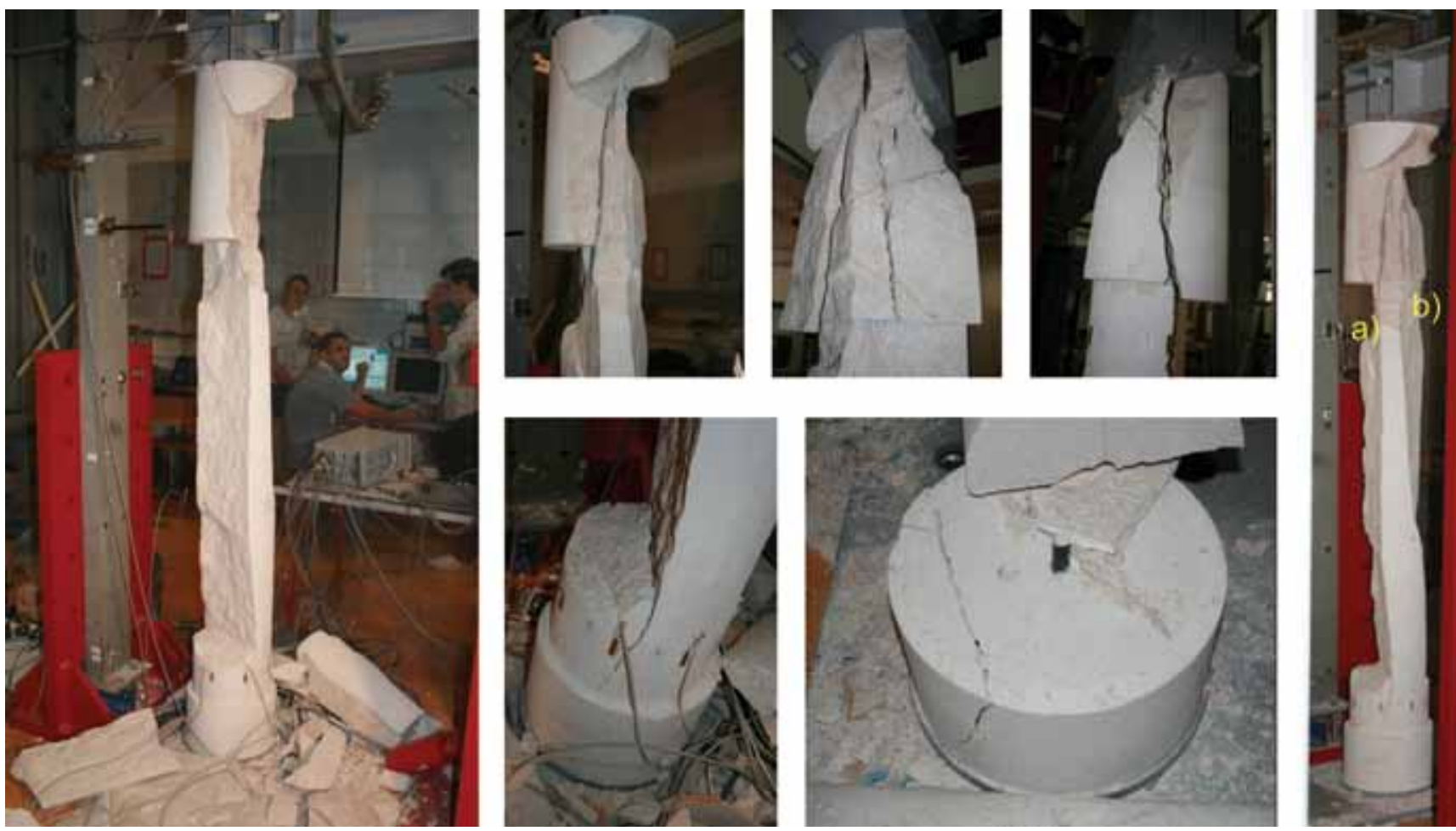

Figure 16. Sample K3 after failure [5]
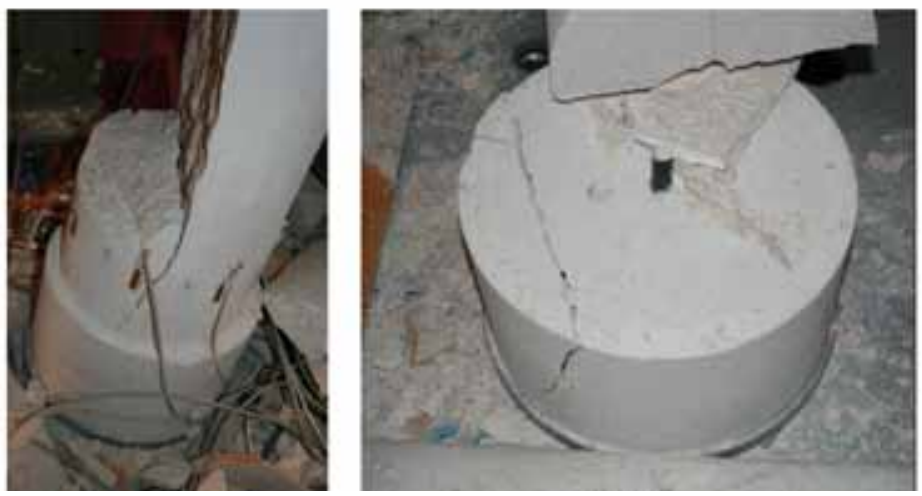

only $4.5 \%$ of the ideal bearing capacity, we can notice the propagation of the joint at the base and, at the place marked at VS (Figure 12.a), the stress value rises to 34.9 MPa. According to stress increase and numerical results, the strength at VS has already been exceeded, but the crack itself is not visible. After that, the eccentric load was applied and a new crack was registered at the centric force of $184.5 \mathrm{kN}$ and at the eccentric force of $66.8 \mathrm{kN}$ (Figure 14.c). The crack occurred at VS near the marked position of stress concentration that was already noted in the test phase (Figure 12.a), and also in numerical models (Figure 13.a). As the position of the initial stress concentration was located on the side of the cross section influenced by capital weight, an additional increase is stress due to capital weight was too great, and the appearance of a 
new crack was unavoidable. Depending on initial sources of stress concentration, the eccentric load can either increase or lower its value, but the tests on other samples also revealed that the crack opening is inevitable.

It is significant to note that eccentric load caused change in the angle of capital rotation with respect to column shaft for negligible $0.033^{\circ}$ ! Similar values were also obtained for other samples, and all this corresponds well with current research results [7]. After the crack opening the described process is repeated, i.e. a new redistribution of stresses around the crack and a new state of balance is registered (Figure 14.a and 14.b).

Subsequent testing and an additional increase in load resulted in a pronounced increase in stress in the vicinity of the capital positioning zone which points to propagation of existing cracks, but also to the opening of new ones. Unfortunately, all testing phases and results at all measurement points can not be described in the paper, and so the accent is placed only on typical behaviour of samples: establishment of stress concentration, crack opening, and redistribution of stress until the bearing capacity at the cross section is exceeded. The failure of the sample K3 occurred only after failure of a major part of the cross section, when the redistribution of stress was no longer possible (Figure 15).

Photographs of the broken sample (Figure 16) confirm the described course of testing, as the column splitting is visible at two points. The first failure surface is near the first crack in VS (marked with a), while the other one (marked with b) is situated in the part of the cross section hat has assumed load after redistribution of stresses (Figure 14.b). In addition, the propagation of the first crack at the base was registered during sample disassembly. Results obtained for the sample K3 have confirmed some basic assumptions of this research, such as the significant damage to column even at a very low centric load, and pronounced susceptibility to eccentric load, i.e. relative rotation between column elements.

Deviation measurements during positioning of sample elements have enabled development of a detailed numerical model by which the state before crack opening can accurately be modelled, i.e. the zone of stress concentration can properly be estimated. It was proven by numerical sensitivity tests that the elimination of deviations also depends on the area and position of contact, but also that stress concentration can greatly be affected by small unevennesses [11]. All has been confirmed by numerical simulations of all tested samples during which the samples were tested, independently from laboratory testing, to centric load of $500 \mathrm{kN}$. An example of results of such simulation for the sample $\mathrm{K} 3$ can be seen in Figure 13.b. The first crack was initiated at the centric force ranging from 135 to $450 \mathrm{kN}$, which represents only 3-10\% of the ideal bearing capacity. However, the sample does not lose its bearing capacity after opening of the first crack, but rather it tries to transfer the load through redistribution of stresses. The development of the model that would include a complex splitting procedure (also present within the cross section) is planned in future phases of the research, which will also include a more complex measurement procedure.

\section{Conclusion}

It can be concluded from results obtained during this research that problems with traditional stone columns start already with relaxation of the keystone. Causes of "permanent occurrences that damage columns", as mentioned in old reports, can be divided into two groups: Firstly, we have unavoidable unevennesses at the contact faces (which are mostly due to the stone treatment method) that prevent realization of the assumed contact along the entire surface and, secondly, the compression line is almost always eccentric which causes rotation of column elements and creates strong concentrations of stress. If we add to this the fact that a specific material such as stone may have initial cracks due to the process of its formation, fabrication and treatment, and due to many events that affect the stone during its use, it is not surprising that many traditional columns are highly affected by cracking. Cracks are a normal occurrence for historic buildings. However, typical occurrences presented in the paper, i.e. formation of stress concentrations, opening of cracks, and redistribution of stress, which include new concentrations, must be analyzed with caution as redistribution is possible only within the cross section of elements.

Today we are excessively oriented by numerous laws and regulations toward preservation of invaluable historic buildings, while an insufficient attention is paid to proper understanding of problems present in this area. This research clearly indicates that by preserving originality we sometimes carefully preserve some structural deficiencies (e.g. traditional connections) that systematically destroy load bearing structural elements. In case of the Rector's Palace in Dubrovnik, the full fracturing of columns has been prevented by sufficiently frequent remedial activities, and so the load bearing capacity of the building has been preserved for a certain time period. Unfortunately, the problem was not eliminated and so the remedied columns are passing once again through the same deterioration process. Fortunately, good shaping of historic buildings (based on verified rules on relationships) has enabled the described redistribution of stress that ensures adequate bearing capacity even when elements are affected by cracking, which has given builders throughout the history an ample time for timely repair, before actual collapse.

We have tried to define, through numerical and experimental investigations, typical behaviour of connections subjected to centric and eccentric load, and hence to provide documented parameters for future analyses of historic buildings. Although it is evident that each traditional column has its own history, it is important to bear in mind the fact that by neglecting real behaviour of traditional connections, we are likely to greatly underestimate the factor of safety, and hence to put in jeopardy the local, and also the global, stability of buildings [19]. Finally, the useful life of a historic building depends on numerous significant details that unfortunately mostly remain neglected. 


\section{REFERENCES}

[1] Steinman, V.: Istražni radovi na Kneževu dvoru u Dubrovniku s načelnim prijedlozima sanacije, knjiga II, Institut gradevinarstva Hrvatske, Zagreb, 1974

[2] Lokošek, E. \& Kleiner, I.: Zamjena kamenih stupova u prizemlju dvorca Veliki Tabor. Građevinar, 56 (2004) 5, pp. 267-276.

[3] Meli, R. \& Sanchez-Ramirez, A. R.: Structural aspects of the rehabilitation of the Mexico City Cathedral, International Seminar on Structural Analysis of Historical Constructions. Possibilities of numerical and experimental techniques, Barcelona, pp. 123140, 1997.

[4] Roca, P. \& Gonzales, J. L.: A summary of the opinions put forward during the discussions, International Seminar on Structural Analysis of Historical Constructions. Possibilities of numerical and experimental techniques, Barcelona, pp. 394-407, 1997.

[5] Lazarević, D., Ataić, J., Uroš, M., Šavor, M. \& Gidak, P.: Utjecaj kontaktnih naprezanja na nosivost stupova tradicijskih gradevina, Sabor hrvatskih graditelja 2012, Cavtat, pp. 217-228, 2012.

[6] Crnković, B. \& Šarić, LJ.: Građenje prirodnim kamenom, IGH Zagreb, 2003.

[7] Lazarević, D., Dvornik, J. \& Fresl, K.: Analiza oštećenja atrija Kneževa dvora u Dubrovniku, Građevinar 56 (2004) 10, pp. 601 612.

[8] Lazarević, D., Atalić, J. \& Fresl, K.: Reconstruction of Rector's Palace atrium in Dubrovnik: a key role of column connections. Structural Studies, Repairs and Maintenance of Heritage Architecture XI, eds. Brebbia, WIT Press, Southampton, pp. 289303, 2009

[9] Heyman, J.: The Stone Skeleton, Cambridge Univ. Press 1995.

[10] Vitruvius, P.M.: De Architectura libri decem, IGH, Zagreb, 1997.

[11] Atalić, J.: Utjecaj kontaktnih naprezanja na nosivost tradicijskih kamenih stupova, doktorski rad, Građevinski fakultet Sveučilišta u Zagrebu, Zagreb, 2011.
[12] Taylor, R.L.: FEAP - A Finite Element Analysis Program, Version 7.3, Programmer Manual, Department of Civil and Environmental Engineering, University of California, Berkley, 2001.

[13] GiD, The universal, adaptive and user friendly pre and post processing system for computer analysis in science and engineering, Version 6, Reference Manual, CIMNE, Barcelona, 2000.

[14] Lazarević, D., Dvornik, J.; Fresl, K. \& Rak, M.: Numerical analysis of damages of the rector's palace atrium in Dubrovnik, Heritage Protection - Construction Aspects, Dubrovnik, pp. 109-116, 2006

[15] SAP2000, Integrated Software for Structural Analysis and Design, Analysis reference manual, CSI: Berkeley, 2002.

[16] Atalić, J., Lazarević, D. \& Šavor, M.:Traditional column connections with iron dowels - experimental and numerical analysis, Proceedings of the International Conference on Structural Analysis of Historical Constructions, SAHC2012,Wroclaw, pp. 619-627, 2012

[17] FaroArm - Overview, www.faro.com, 1.6.2012.

[18] Lazarević, D., Atalić, J., Krolo, J., Uroš, M. \& Šavor, M.: Experimental and Numerical Analysis of Traditional Column Connections with the Possible Retrofit Concept, Advanced Materials Research, Vols. 133-134: pp. 479-484, 2010.

[19] Atalić, J., Lazarević, D. \& Fresl, K.: Influence of Rotational Stiffness between Column Elements on Global Stability of Historical Constructions. Proc. of the 8th European Conference on Research for Protection, Conservation and Enhancement of Cultural Heritage, Ljubljana, pp. 60-62, 2008.

[20] Gubane, A. \& Giuriania, E.: Structural restoration of vaults with extrados ties. International Seminar Structural Analysis of Historical Constructions IV. Possibilities of numerical and experimental techniques, Padova, pp. 745-752, 2004.

[21] Theodossopoulos, D.: Structural design of high gothic vaulting systems in England. International Journal of Architectural Heritage 2(1): pp. 1-24, 2008 